\title{
Influence of steam on gasification of millimetric wood particles in a drop tube reactor: Experiments and modelling
}

\author{
Santiago Septien ${ }^{\mathrm{a}}$, Sylvie Valin ${ }^{\mathrm{a}, *}$, Marine Peyrot $^{\mathrm{a}}$, Bertrand Spindler ${ }^{\mathrm{a}}$, Sylvain Salvador ${ }^{\mathrm{b}}$ \\ ${ }^{a}$ CEA, LITEN, DTBH/LTB, 38054 Grenoble, France \\ ${ }^{\mathrm{b}}$ RAPSODEE, UMR-CNRS 5302, Ecole des Mines d'Albi, 81013 Albi, France
}

\author{
Keywords: \\ Biomass \\ Steam \\ Gasification \\ Drop tube reactor \\ Modelling
}

\section{H I G H L I G H T S}

- Wood particles were gasified in a drop tube reactor at $1000-1400{ }^{\circ} \mathrm{C}$.

- The influence of the presence of steam in the atmosphere was investigated.

- The particle size - 0.35-0.80 mm - has no influence on experimental products yields.

- After $4.4 \mathrm{~s}$ at $1400^{\circ} \mathrm{C}$ with steam, the char is totally gasified but soot still remains.

- A comprehensive model was developed, which satisfactorily simulates the experiments.

\begin{abstract}
A B S T R A C T
Wood particle conversion in a drop tube reactor was studied between $1000^{\circ} \mathrm{C}$ and $1400^{\circ} \mathrm{C}$, both with experiments and simulations using a comprehensive model. Particular attention was paid to the influence of steam on the gasification process, and to the wood particle size. The model included a description of the different phenomena involved in biomass conversion: pyrolysis, gas phase reactions, soot formation and carbonaceous solid gasification. Satisfactory results were obtained in comparison with experiments.

The addition of steam in the atmosphere influenced char, tar, soot and gas yields, especially at $1200{ }^{\circ} \mathrm{C}$ and $1400^{\circ} \mathrm{C}$. These changes were linked to char and soot steam gasification, and to gas phase reactions, among which hydrocarbons steam reforming and water-gas shift.

At $1400{ }^{\circ} \mathrm{C}$, with $25 \mathrm{~mol} \% \mathrm{H}_{2} \mathrm{O}$ and after a residence time of $4.4 \mathrm{~s}$, the char seems to be completely gasified, while the soot yield still represents about $5 \mathrm{wt} \%$ of the initial dry biomass.

Wood particle size in the range $0.35-0.80 \mathrm{~mm}$ was experimentally shown to have no influence on products yields for a residence time of a few seconds.
\end{abstract}

\section{Introduction}

Entrained flow reactor is one of the most promising biomass gasification technologies for biofuel production. Even if this technology is well advanced on an industrial scale for coal gasification, the development of reactors fed with biomass has not really been achieved yet. The main advantage of this technology is the high conversion of biomass into a syngas with very low tar and hydrocarbons contents. The entrained flow reactor (EFR) is characterised by high operating temperatures, above $1300^{\circ} \mathrm{C}$. The particles are introduced under a pulverized form and, submitted to a high heating flux, are converted into syngas in a short residence time of a few seconds. On the basis of the experience feedback on coal injection and gasification in EFR, particles size is recommended to be

\footnotetext{
* Corresponding author. Tel.: +33 438784358; fax: +33 438785251

E-mail address: sylvie.valin@cea.fr (S. Valin).
}

under $200 \mu \mathrm{m}$. This implies high additional costs in the process due to wood grinding and/or pre-treatment such as torrefaction in order to transform biomass into a material which can be more easily ground [1]. So the use of larger particles, of approximately $1 \mathrm{~mm}$, would be of interest, but it has to be proved that such large particles can be completely converted in the EFR [2].

The phenomenology linked to biomass conversion in conditions similar to those of an EFR has rarely been studied until now. Under a high heating flux, biomass particles, as they enter the reactor, are submitted to fast pyrolysis which mainly produces $\mathrm{H}_{2}, \mathrm{H}_{2} \mathrm{O}, \mathrm{CO}$, $\mathrm{CO}_{2}$, light and heavy hydrocarbons (tar) and char. Hydrocarbons then undergo complex reactions of cracking and polymerization, which can lead to soot particles formation. These carbon-rich particles can induce some operational problems in the process, such as blocking or fouling of equipments, and must be removed from the gas. In the presence of an oxidising gas (steam, oxygen, carbon dioxide), hydrocarbons can be reformed, and the carbonaceous solids can be gasified. 
The drop tube reactor (DTR) is an experimental apparatus well adapted to study biomass conversion in the conditions of an EFR at the laboratory scale. Even if the phenomena listed above cannot be completely decoupled, a variation in the composition of the atmosphere can allow isolation of some of them: pyrolysis and hydrocarbon cracking/polymerization reactions are the main phenomena occurring in an inert atmosphere, while hydrocarbon reforming and solid gasification also play an important role in a steam containing atmosphere.

Few works in the literature deal with biomass gasification studies in a DTR at temperatures above $1000{ }^{\circ} \mathrm{C}$, either in an inert atmosphere [3-5], or an atmosphere containing steam and/or oxygen [5-8]. These works show that the gas yield from fast pyrolysis is higher than $80 \mathrm{wt} \%$ of dry biomass for particles smaller than $0.5 \mathrm{~mm}$ above $800{ }^{\circ} \mathrm{C}[4,9]$. The main gaseous products are $\mathrm{CO}$, $\mathrm{CO}_{2}, \mathrm{H}_{2}, \mathrm{H}_{2} \mathrm{O}, \mathrm{CH}_{4}$, and also in smaller amounts $\mathrm{C}_{2} \mathrm{H}_{2}, \mathrm{C}_{2} \mathrm{H}_{4}, \mathrm{C}_{2} \mathrm{H}_{6}$ and $\mathrm{C}_{6} \mathrm{H}_{6}$; gas composition varies with temperature. Tar, char and soot are the other pyrolysis products. Soot is already detected at $900{ }^{\circ} \mathrm{C}$, but its yield is the highest around $1100-1200^{\circ} \mathrm{C}$, where it can reach about $15 \mathrm{wt} \%$ of dry biomass in an inert atmosphere $[4,5]$. The char yield was shown to be lower at $800^{\circ} \mathrm{C}$ or above with the addition of steam in the atmosphere [5,7]. The same influence was shown for soot yield $[5,8]$.

In order to better understand the different phenomena which control biomass conversion, a comprehensive modelling tool can be useful. This model should include a representation of biomass pyrolysis, of carbonaceous solid gasification, of gas phase reactions and if possible of soot formation. Few researchers have developed models with such characteristics for biomass gasification in an EFR or DTR. Vilas et al. focused on the biomass reburning phenomenon [10]; the CMIC department at Politechnico di Milano also developed a modelling tool including a detailed description of biomass particles pyrolysis [11-13].

The present study aims to investigate wood particle conversion in a drop tube reactor between $1000^{\circ} \mathrm{C}$ and $1400^{\circ} \mathrm{C}$, both with experiments and simulations. Particular attention is paid to the influence of steam on the gasification process, and to wood particle size, which has very rarely been studied in these conditions [3]. The experiments were conducted in a DTR with beech wood particles of $0.35 \mathrm{~mm}$ and $0.80 \mathrm{~mm}$ as feedstock. First results obtained in an inert atmosphere were already presented in another publication [14], and will be used here for comparison purposes. An existing model was adapted to represent wood particles conversion in a DTR, and was validated by comparisons with the experimental results. It was then used to get a better understanding of the experimentally observed phenomena.

\section{Experimental}

\subsection{Biomass samples}

The feedstock used in this study is beech sawdust. Two particles sizes ranges were selected after sieving: $0.313-0.400 \mathrm{~mm}$ and $0.730-0.900 \mathrm{~mm}$. These samples are referred to as $0.35 \mathrm{~mm}$ and $0.80 \mathrm{~mm}$ particles samples respectively.

The proximate analysis (ash, moisture, volatile matter and fixed carbon) and the ultimate analysis $(\mathrm{C}, \mathrm{H}, \mathrm{O}, \mathrm{N}, \mathrm{S})$ of the two samples are shown in Table 1 . No significant difference between the compositions of the two samples is confirmed.

\subsection{Description of the drop tube reactor}

The drop tube reactor (DTR) is represented in Fig. 1. It consists of an alumina tube inserted in a vertical electrical heater with three independent heating zones. The dimensions of the tube are
Table 1

Proximate and ultimate analyses of beech sawdust samples.

\begin{tabular}{lll}
\hline & $0.35 \mathrm{~mm}$ particles & $0.80 \mathrm{~mm}$ particles \\
\hline Proximate analysis & & \\
Moisture (wt\%) & 7 & 7 \\
Volatile matter (wt\% dry basis) & 85.3 & 85.3 \\
Fixed carbon (wt\% dry basis) & 14.3 & 14.3 \\
Ash (wt\% dry basis) & 0.4 & 0.4 \\
Ultimate analysis (wt\% dry, ash free basis) & \\
C & 50.8 & 50.4 \\
H & 5.9 & 5.9 \\
N & 0.3 & 0.3 \\
S & 0.02 & 0.02 \\
$\mathrm{O}^{\text {a }}$ & 42.9 & 43.3 \\
\hline
\end{tabular}

a By difference.

$2.3 \mathrm{~m}$ in length and $0.075 \mathrm{~m}$ in internal diameter. The heated zone is $1.2 \mathrm{~m}$ long. The DTR works at atmospheric pressure and can reach a maximum temperature of $1600^{\circ} \mathrm{C}$.

The wood particles are continuously fed into the reactor using a gravimetric feeding system, which consists of a feedstock hopper on a conveyor belt. The whole system is placed on a balance and is connected to a computer. The conveyor belt velocity is controlled so as to follow the set point of the feeding flow rate. The wood particles initially introduced in the hopper are entrained by the conveyor belt to a vibrating channel and then to a pneumatic ejector from which they are injected into the reactor with a $2 \mathrm{NL} \mathrm{min}^{-1}$ transport nitrogen stream through a water-cooled $\left(30^{\circ} \mathrm{C}\right)$ feeding probe. A dispersion dome is placed at the outlet of the feeding probe to distribute the solid particles over the reactor cross section.

The main gas stream, which can be $\mathrm{N}_{2}$ or a mixture of $\mathrm{N}_{2}$ and $\mathrm{H}_{2} \mathrm{O}$, is electrically pre-heated before entering the reactor. For the introduction of $\mathrm{H}_{2} \mathrm{O}$ into the DTR, a steam generator working at $180^{\circ} \mathrm{C}$ is linked to the reactor inlet.

An oil-cooled $\left(110^{\circ} \mathrm{C}\right)$ sampling probe can be inserted at different heights in the bottom half of the reactor to collect gas and the remaining solid. A fraction of the exhaust gas is sucked in the sampling probe and passes through a settling box and a filter. This part of the experimental facility is heated $\left(150^{\circ} \mathrm{C}\right)$ to avoid steam condensation. After the filter, the sampled gas passes through a condenser if steam is introduced into the reactor, and is finally analyzed.

Different analyzers are available for gas analyses, and have been described in details in a previous article [14]. The micro-gas chromatograph $(\mu-G C)$ concentrations were considered for quantification of the major gases $\left(\mathrm{CO}_{2}, \mathrm{CO}, \mathrm{CH}_{4}, \mathrm{~N}_{2}, \mathrm{H}_{2}\right)$, as well as benzene. For quantification of $\mathrm{C}_{2} \mathrm{H}_{2}, \mathrm{C}_{2} \mathrm{H}_{4}, \mathrm{C}_{2} \mathrm{H}_{6}$, the FTIR (Fourier Transformed InfraRed) spectrometer value was considered. A Flame Ionization Detector (FID) also gives the total hydrocarbons content of the gas. $\mathrm{H}_{2} \mathrm{O}$ was measured by a psychrometer in the case of experiments under nitrogen. For experiments in a wet atmosphere, the water yield was not determined. Indeed, water condensation at the outlet of the reactor (in the condenser) appeared to be not efficient enough for a precise quantification by weighing.

\subsection{Conditions of the experiments}

Experiments were performed in a nitrogen inert atmosphere and a steam containing atmosphere $\left(25 \mathrm{~mol} \% \mathrm{H}_{2} \mathrm{O}-75 \mathrm{~mol} \% \mathrm{~N}_{2}\right)$, at several temperatures, $1000^{\circ} \mathrm{C}, 1200^{\circ} \mathrm{C}$ and $1400{ }^{\circ} \mathrm{C}$, and with each of the two particle size samples (Table 1 ). Gas sampling was performed at two different levels, after $0.6 \mathrm{~m}$ - middle of the heated zone - or $1.2 \mathrm{~m}$ of reaction length. Only at $1400{ }^{\circ} \mathrm{C}$ no 


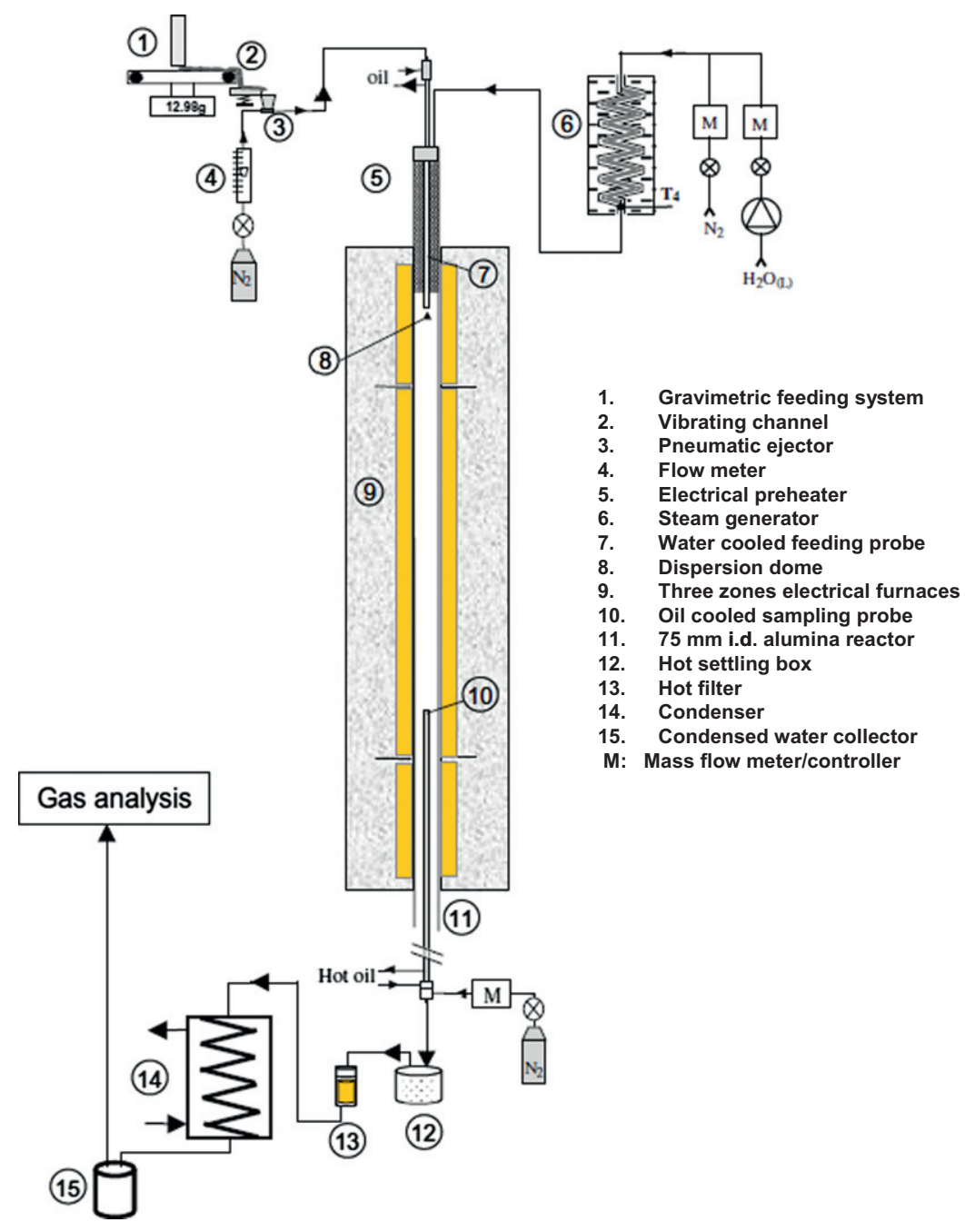

Fig. 1. Scheme of the drop tube reactor.

Table 2

Inlet gas flow rate and gas residence time for experiments in the DTR.

\begin{tabular}{llll}
\hline $\begin{array}{l}\text { Temperature of the } \\
\text { experiment }\left({ }^{\circ} \mathrm{C}\right)\end{array}$ & $\begin{array}{l}\text { Inlet gas flow rate } \\
\left.(\mathrm{NL} \mathrm{min})^{-1}\right)\end{array}$ & $\begin{array}{l}\text { Reaction } \\
\text { length }(\mathrm{m})\end{array}$ & $\begin{array}{l}\text { Gas residence } \\
\text { time }(\mathrm{s})\end{array}$ \\
\hline 1000 & 15.9 & 0.6 & 2.2 \\
& & 1.2 & 4.4 \\
1200 & 13.8 & 0.6 & 2.2 \\
& & 1.2 & 4.4 \\
1400 & 12.1 & 1.2 & 4.4 \\
\hline
\end{tabular}

experiment could be performed with sampling at the middle of the heated zone because of cooling oil overheating.

The atmosphere gas flow rate at the inlet was varied in order to keep a constant gas velocity and thus a constant gas residence time for experiments at different temperatures (Table 2). Due to slip velocity, the residence time of the $0.80 \mathrm{~mm}$ particles was lower than the residence time of the $0.35 \mathrm{~mm}$ particles, which was shown to be roughly equal to the gas residence time [14]. Note that the experiments were performed under diluted condition, as the total gas flow rate was hardly modified by gas release from biomass thermal decomposition.

Biomass feeding rate was varied between $0.3 \mathrm{~g} \mathrm{~min}^{-1}$ and $1.3 \mathrm{~g} \mathrm{~min}^{-1}$. In this range, no influence of feeding rate on products yields was observed.
Our DTR is designed for small biomass feeding rates and for working in diluted conditions. So it was not possible, for tests in a steam containing atmosphere, to find operating conditions which would give representative values of steam/biomass inlet rates ratio and atmospheric steam partial pressure of an industrial EFR. Steam was in a large stoichiometric excess, about 30-35 times higher than the quantity needed for the gasification of all the carbon introduced into the reactor. However, steam partial pressure was fixed at $25 \mathrm{~mol} \%$, a value close to the one encountered in an EFR.

In the experiments, different kinds of solids - char and soot were recovered in the sampling line. Char was mainly found in the settling box, whereas soot particles were mainly observed in the filter.

\subsection{Gas and solids yields determination}

The gas yields were determined from the gas composition measurements and the nitrogen inlet flow rate, using nitrogen as a tracer. An estimation of the relative error based on repeatability experiments gives $\pm 5 \%$ for $\mathrm{H}_{2}$ and CO yields ( $\mathrm{g} / \mathrm{g}$ of dry biomass), $\pm 10 \%$ for $\mathrm{CO}_{2}, \mathrm{H}_{2} \mathrm{O}$ and $\mathrm{CH}_{4}$ yields, and $\pm 20 \%$ for $\mathrm{C}_{2} \mathrm{H}_{2}, \mathrm{C}_{2} \mathrm{H}_{4}, \mathrm{C}_{2} \mathrm{H}_{6}$ and $\mathrm{C}_{6} \mathrm{H}_{6}$ yields.

Char was recovered into the settling box, and its ash content was measured. As already detailed previously [14], its yield was calculated using the ash tracer method. The relative error for the char yield is estimated at $\pm 25 \%$. 
Tar and soot yields could not be directly quantified. In particular, it appeared that soot particles could not be all collected on the filter, as a part of them remained in the sampling probe and could not be quantified. So the lacking mass in the calculated global mass balance for experiments in nitrogen, and in the calculated carbon mass balance for experiments in a wet atmosphere, was attributed to soot and tar. This means that for the latter type of experiments, the hydrogen and oxygen contents of tar and soot were neglected. The soot recovered at the bottom of the DTR was found to be composed of more than $99.2 \mathrm{wt} \%$ of carbon [15], which validates this assumption for soot. As for tar, the study of Zhang et al. [5] performed in conditions similar to ours show that for experiments in a steam containing atmosphere, at $1000^{\circ} \mathrm{C}$ and above, carbon represents more than $93.5 \mathrm{wt} \%$ in tars. Moreover, the same authors show that the tar yield at $1200{ }^{\circ} \mathrm{C}$ and above is negligible, which was confirmed in our study, as detailed in Section 4.1. So, our assumption implies that at $1000^{\circ} \mathrm{C}$ only in a wet atmosphere, the experimental tar + soot yield could be a bit underestimated, of $6.5 \%$ at maximum.

Moreover, the uncertainty derived from repeatability experiments for the tar and soot yield is estimated to be of $\pm 25 \%$. These two sources of errors were taken into account for representation of tar + soot yields (Figs. 2, 6 and 11)

\section{Modelling}

The experiments were simulated using a numerical model named GASPAR, which allows modelling a drop tube reactor. The GASPAR software, originally developed for thermochemical applications such as combustion and pollutants formation [16-18], was modified in order to adapt it to biomass gasification [19], and specifically in this study for biomass gasification above $1000^{\circ} \mathrm{C}$.

\subsection{The GASPAR model}

For the experiments described above, the gas flow in the tubular reactor is laminar (Reynolds number between 600 and 1000). The drop tube reactor is modelled by a plug flow reactor. A Lagrangian approach is used to represent the biomass particles, which are here considered to be spherical. Particle isothermicity assumption is made and no slip between the gas and the particles is considered. The entire flow in the drop tube reactor is simulated as the sum of elementary parts, each one representing a single particle and the surrounding gas volume associated to it. The model simulates the time or space evolution of these samples along the reactor, which are equivalent here. The model can be therefore qualified as a $0 \mathrm{D}$ model. As a consequence, it does not allow to completely characterize the reactor temperature and hydraulics, contrary to CFD simulations used by other authors in complement to biomass pyrolysis experiments in drop tube reactors [20,21].

Gas phase reactions are computed using subroutines from CHEMKIN II software using a detailed chemical mechanism [22]. The model includes thermal and chemical phenomena:

- heating of carrier gas (convection and radiation) and of wood particles (external conduction and radiation), described in more details in [16];

- particle drying using an Arrhenius law;

- chemical reactions: particle pyrolysis, gas phase reactions including soot formation, soot and char gasification.

The gas temperature profile calculated along the drop tube reactor was validated against measurements performed at several heights in the reactor.
All the differential equations are simultaneously time integrated with the help of the Gear algorithm that can solve stiff ordinary differential equation systems [23]. The whole model is included in a FORTRAN program. The model is able to predict with a very low running time (under $20 \mathrm{~s}$ ) the evolution of several variables versus the gas residence time: char, gas, soot and tar yields, particle temperature, and also gas composition with all the species considered in the detailed kinetic scheme. Note that as slip particle velocity is neglected in these simulations, solid and gas residence times are equal. Therefore, the model results are compared to the experimental results obtained with $0.35 \mathrm{~mm}$ wood particles only, for which the slip velocity can be neglected.

Each chemical phenomenon is described below in more details.

\subsection{Pyrolysis}

The term "pyrolysis" here refers to biomass devolatilization and vapour thermal cracking. Pyrolysis is modelled by a one-step reaction, where biomass is decomposed into volatile species and a carbonaceous residue, the char.

The time evolution of the dry biomass weight $m_{\text {dry biomass }}$ is expressed by the following relation:

$\frac{d m_{\text {dry biomass }}}{d t}=-m_{\text {dry biomass }} k_{\text {pyro }}$

$k_{\text {pyro }}\left(\mathrm{s}^{-1}\right)$ is the pyrolysis kinetic parameter, and is expressed by means of an Arrhenius law:

$k_{\text {pyro }}=k_{0, p y r o} \exp \left(-\frac{E_{a, p y r o}}{R T}\right)$

with $k_{0, p y r o}=74 \times 10^{3} \mathrm{~s}^{-1}$ and $E_{a, p y r o}=70 \times 10^{3} \mathrm{~J} \mathrm{~mol}^{-1}$. These values were adjusted on experimental results obtained for biomass pyrolysis at $800^{\circ} \mathrm{C}$ in the same reactor $[9,19]$.

The products are gaseous species $\left(\mathrm{H}_{2}, \mathrm{CO}, \mathrm{H}_{2} \mathrm{O}, \mathrm{CO}_{2}, \mathrm{CH}_{4}, \mathrm{C}_{2} \mathrm{H}_{2}\right.$, $\mathrm{C}_{2} \mathrm{H}_{4}, \mathrm{C}_{2} \mathrm{H}_{6}, \mathrm{C}_{3} \mathrm{H}_{8}, \mathrm{C}_{6} \mathrm{H}_{6}$ ), char, and tar compounds, for which model species were searched. For experiments in an inert atmosphere at $800{ }^{\circ} \mathrm{C}$ in the same DTR, tar were shown to have a mean formula close to $\mathrm{C}_{n} \mathrm{H}_{n} \mathrm{O}_{0.2 n}$ [15]; this suggests that tar is a mixture of oxygen containing and aromatic hydrocarbons. This is in agreement with the experimental results of Zhang et al. [4] obtained under similar conditions, who found out that methanol, phenol, toluene and naphthalene were the main tar species at $800^{\circ} \mathrm{C}$. Among these species, phenol was not selected as its decomposition was not correctly represented in the kinetic scheme selected for gas phase reactions modelling (Section 3.3). It appeared then that a combination between methanol $-\mathrm{CH}_{3} \mathrm{OH}$ - and naphthalene $-\mathrm{C}_{10} \mathrm{H}_{8}$ - only was the best to represent our tar composition. These two model compounds were introduced in the gas phase and their reactions were modelled with the same detailed kinetic scheme as the one used for all other gaseous compounds. Char is supposed to be composed of carbon only.

So, biomass pyrolysis is altogether represented by the reaction:

$$
\begin{aligned}
\mathrm{C}_{w} \mathrm{H}_{x} \mathrm{O}_{y}+z \mathrm{H}_{2} \mathrm{O} \rightarrow & a \mathrm{H}_{2}+b \mathrm{CO}+c \mathrm{CO}_{2}+d \mathrm{H}_{2} \mathrm{O}+e \mathrm{CH}_{4} \\
& +f \mathrm{C}_{2} \mathrm{H}_{2}+g \mathrm{C}_{2} \mathrm{H}_{4}+h \mathrm{C}_{2} \mathrm{H}_{6}+i \mathrm{C}_{3} \mathrm{H}_{8}+j \mathrm{C}_{6} \mathrm{H}_{6} \\
& +k \mathrm{C}+m \mathrm{CH}_{3} \mathrm{OH}+n \mathrm{C}_{10} \mathrm{H}_{8}+\mathrm{C}_{s} \mathrm{H}_{t} \mathrm{O}_{u}
\end{aligned}
$$

where the dry biomass $\mathrm{C}_{w} \mathrm{H}_{x} \mathrm{O}_{y}$ has been individualized from its moisture. The composition of the biomass is indicated in Table 3. A "rest" with the mean formula $\mathrm{C}_{s} \mathrm{H}_{t} \mathrm{O}_{u}$ was introduced into the reaction so that the stoichiometry is respected. Physically, the mass fraction of this rest can be attributed to tar. In the model, as this rest does not correspond to any identified molecule, the choice was made that it would not participate in any other reaction.

The coefficients $a, b, c, d, e, f, g, h, i, j$, and $k$ were determined from previous experiments under an inert atmosphere at $800^{\circ} \mathrm{C}$ 
Table 3

Dry biomass formula and moisture coefficient.

\begin{tabular}{llll}
\hline$w$ & $x$ & $y$ & $z$ \\
\hline 6 & 8.2583 & 3.7654 & 0.5894 \\
\hline
\end{tabular}

[15]. The products in these conditions are assumed to mainly result from pyrolysis and tar cracking, which are supposed in the model to give the same products at any temperature higher than $800^{\circ} \mathrm{C}$. This means in particular that the char yield from the pyrolysis step is assumed to be independent on temperature between 800 and $1400^{\circ} \mathrm{C}$. This hypothesis lies on several experimental observations: in our previous experiments in an inert atmosphere, we observed that the char yield was steady between 800 and $1200{ }^{\circ} \mathrm{C}$ [14]; this is in agreement with the experimental findings of Zhang et al. [4] who observed a plateau in char yield between 800 and $1100{ }^{\circ} \mathrm{C}$ for pyrolysis of Hinoki cypress sawdust.

Having made the choice that methanol and naphthalene would represent all tar, the coefficients $m$ and $n$ were adjusted in order to minimize the coefficients $s, t$ and $u$. The mass of the rest then represents less than $3 \mathrm{wt} \%$ of initial dry biomass. A single set of parameters was used for all simulations (Table 4).

\subsection{Gas phase reactions and soot formation}

The Skjøth-Rasmussen and co-workers kinetic scheme (159 species, 773 reactions) [24] was selected for gas phase modelling. This kinetic scheme can predict the Polycyclic Aromatic Hydrocarbons (PAH) formation, which play an important role in soot formation. It was validated with a series of methane oxidation experiments in a plug-flow reactor, some of them in the presence of steam [24]. This mechanism was compared with a good accuracy to gas phase experiments between $1000^{\circ} \mathrm{C}$ and $1400^{\circ} \mathrm{C}$ on gas mixtures with a composition representative of biomass pyrolysis gas [25].

Soot formation implies several steps [26]:

- Nucleation: the primary soot particles, whose size is under $20 \mathrm{~nm}$, are formed from the inception of two PAH molecules,

- Surface growth, by the addition of $\mathrm{C}_{2} \mathrm{H}_{2}$ or of PAH molecules on the primary particles surface,

- Coagulation of primary soot particles.

Surface growth and coagulation lead to the formation of spherical particles of several tens of nm, called spherules. Finally, these spherules agglomerate to form cluster-like or chain-like micrometric structures.

Some models of soot formation represent the elementary soot formation steps in a simplified [27] or detailed [28] way. The existing models can predict soot mass yield, particles number density and even soot composition for the most complex ones. The present study focuses on the modelling of soot mass yield only, which can be compared to experimental results.
In the selected kinetic scheme [24], soot formation can be modelled by the collision of two pyrene molecules, which corresponds to the particle inception step. However, this approach did not give satisfactory results in our conditions as soot formation modelling through particle inception only is not complete. In fact, its use would require the introduction of complex parameters for the representation of mass growth in order to obtain more accurate results, while a simple approach is suitable in the present study. So, another soot formation model was developed in this work and introduced in the kinetic scheme. In this model, soot is formed from $\mathrm{C}_{2} \mathrm{H}_{2}$ and from all $\mathrm{PAH}$, following one-step independent reactions where soot particles inception and surface growth are implicitly included. Soot is assumed to be composed of carbon only. In our calculations, the main PAH compounds formed by gas phase reactions and considered as soot precursors are: naphthalene $\left(\mathrm{C}_{10} \mathrm{H}_{8}\right)$, acenaphthalene $\left(\mathrm{C}_{12} \mathrm{H}_{8}\right)$, phenanthrene $\left(\mathrm{C}_{14} \mathrm{H}_{10}\right)$, fluoranthene $\left(\mathrm{C}_{16} \mathrm{H}_{10}\right)$, and pyrene $\left(\mathrm{C}_{16} \mathrm{H}_{10}\right)$.

The reactions leading to soot formation are written below, where PAHs are represented by the general formula $\mathrm{C}_{n} \mathrm{H}_{m}$ :

$$
\begin{aligned}
& \mathrm{C}_{2} \mathrm{H}_{2} \rightarrow 2 \mathrm{C}_{\text {soot }}+\mathrm{H}_{2} \\
& \mathrm{C}_{n} \mathrm{H}_{m} \rightarrow n \mathrm{C}_{\text {soot }}+\frac{m}{2} \mathrm{H}_{2}
\end{aligned}
$$

Each reaction kinetic is supposed to follow a first order Arrhenius law with respect to $\mathrm{C}_{2} \mathrm{H}_{2}$ or $\mathrm{PAH}$ concentration. The same activation energy as that obtained by Ziegler [27] for soot formation from $\mathrm{C}_{2} \mathrm{H}_{2}$ in propane pyrolysis experiments $\left(E_{\mathrm{a}}=167 \times 10^{3}\right.$ $\mathrm{J} \mathrm{mol}^{-1}$ ) was used for reactions (4) and (5). As shown before, $\mathrm{C}_{2} \mathrm{H}_{2}$ and PAH participate in soot formation following different mechanisms, thereby a different pre-exponential factor was used for reactions (4) and (5). These factors were adjusted in order to minimize the difference between experimental and calculated $\mathrm{C}_{2} \mathrm{H}_{2}$ and $\operatorname{tar}+$ soot yields in an inert atmosphere at $1000^{\circ} \mathrm{C}$ and $1200{ }^{\circ} \mathrm{C}$.

The values of the pre-exponential factors obtained by this fitting are $1.0 \times 10^{6} \mathrm{~s}^{-1}$ and $5 \times 10^{6} \mathrm{~s}^{-1}$ for reactions (4) and (5) respectively.

\subsection{Char and soot particles gasification}

According to a previous analysis based on characteristic times comparison, char particles gasification is controlled by chemical reaction only and not by steam mass transfer in the conditions of our experiments in a wet atmosphere with the $0.35 \mathrm{~mm}$ wood particles [15]. The same result was obtained for soot particles steam gasification.

Kinetic models previously developed on the basis of thermogravimetric analysis experiments with soot and char samples recovered in the drop tube reactor facility were introduced into GASPAR. The kinetic laws taken from [15] are given in Table 5 as a function of the conversion $X$, which is calculated as:

Table 4

\begin{tabular}{|c|c|c|c|c|c|c|c|c|c|c|c|c|}
\hline \multicolumn{13}{|c|}{ Coefficients of the pyrolysis reaction (3) } \\
\hline$a$ & $b$ & $c$ & $d$ & $e$ & $f$ & $g$ & $h$ & $i$ & $j$ & $k$ & $m$ & $n$ \\
\hline 0.6999 & 2.0156 & 0.3527 & 1.2557 & 0.4549 & 0.070 & 0.220 & 0.0233 & 0 & 0.0179 & 0.5286 & 0.3099 & 0.1445 \\
\hline \multicolumn{13}{|c|}{ Formula for "rest" } \\
\hline$s$ & & & & & & $t$ & & & & & & $u$ \\
\hline 0.1590 & & & & & & 0.0433 & & & & & & 0.0684 \\
\hline
\end{tabular}

Values of the parameters fixed in reaction (3). 
Table 5

Kinetic laws used for char and soot particles gasification (from [21]).

\begin{tabular}{lll}
\hline & Char & Soot \\
\hline Kinetic law & $\frac{d X}{d t}=k\left(T, P_{\mathrm{H} 2 \mathrm{O}}\right)(1-X)(1-\ln (1-X))^{1 / 2}$ & $\frac{d X}{d t}=k\left(T, P_{\mathrm{H} 2 \mathrm{O}}\right)(1-X)$ \\
$k\left(T, P_{\mathrm{H} 2 \mathrm{O}}\right)$ & $217893 \times \exp \left(\frac{-149.10^{3}}{R T}\right) P_{\mathrm{H} 2 \mathrm{O}}^{0.7}$ & $345915 \times \exp \left(\frac{-178.10^{3}}{R T}\right) P_{\mathrm{H} 2 \mathrm{O}}^{0.7}$ \\
\hline
\end{tabular}

$X=1-\frac{m(t)}{m(t=0)}$

where $m$ is the mass of char or soot $(\mathrm{kg})$ and $t$ is the time $(\mathrm{s})$.

Gasification by steam only was considered in the model.

\section{Results and discussion}

The experimental char, tar + soot and gas yields obtained for $0.35 \mathrm{~mm}$ wood particles are firstly presented in Section 4.1, with a special focus on the influence of steam in the atmosphere. The simulation results are then compared to the experimental ones in Section 4.2, at all temperatures and for both inert and wet atmospheres. The experimental results for $0.80 \mathrm{~mm}$ particles are finally presented in Section 4.3 where they are compared to the $0.35 \mathrm{~mm}$ particles experimental results.

\subsection{Influence of steam on the experimental results}

The total dry gas $\left(\mathrm{H}_{2}, \mathrm{CO}, \mathrm{CO}_{2}, \mathrm{CH}_{4}, \mathrm{C}_{2} \mathrm{H}_{2}, \mathrm{C}_{2} \mathrm{H}_{4}, \mathrm{C}_{6} \mathrm{H}_{6}\right)$, char and tar + soot mass yields obtained for $0.35 \mathrm{~mm}$ particles under an inert atmosphere at the bottom of the reactor, already presented in [14], are compared to the yields obtained under a wet atmosphere $\left(25 \% \mathrm{H}_{2} \mathrm{O}, 75 \% \mathrm{~N}_{2}\right)$ in Fig. 2 . Note that the total dry gas mass yield was divided by 10 to be represented on the same scale as char and tar + soot

As explained before, the sum of tar and soot yields was determined by difference from the mass balance. At $1200^{\circ} \mathrm{C}$ and $1400{ }^{\circ} \mathrm{C}$, the experimental observations showed that almost no tar was present in the DTR. Besides, the sum of $\mathrm{CH}_{4}, \mathrm{C}_{2}$ species and $\mathrm{C}_{6} \mathrm{H}_{6}$ molar fractions, measured by $\mu-\mathrm{GC}$ and FTIR at the output, was equal to the total hydrocarbons content measured by FID. This means that the experimental tar yield at $1200^{\circ} \mathrm{C}$ and $1400^{\circ} \mathrm{C}$ is negligible, so the experimental "tar + soot" mass yield at $1200{ }^{\circ} \mathrm{C}$ and $1400{ }^{\circ} \mathrm{C}$ is considered to be that of soot.

Fig. 2 shows that the (tar+) soot yield is higher under an inert atmosphere at all temperatures, with a significant difference at

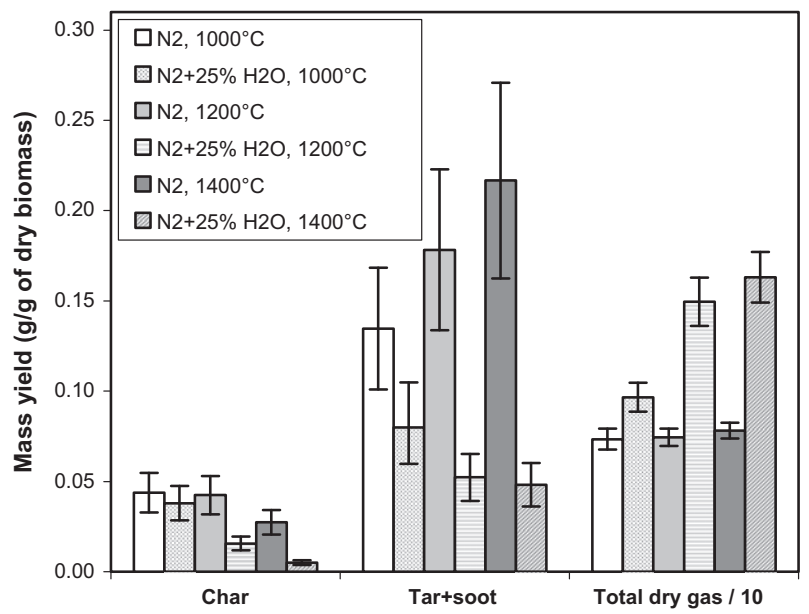

Fig. 2. Experimental mass yields of char, tar + soot, and total dry gas under inert and wet atmospheres at $1000{ }^{\circ} \mathrm{C}, 1200{ }^{\circ} \mathrm{C}$ and $1400{ }^{\circ} \mathrm{C}$.
$1200{ }^{\circ} \mathrm{C}$ and $1400{ }^{\circ} \mathrm{C}$. Note that the soot yield still represents about $5 \mathrm{wt} \%$ of the initial dry biomass in a wet atmosphere at $1400{ }^{\circ} \mathrm{C}$. This result shows that even at high temperature with significant steam content in the atmosphere, soot particles cannot be completely avoided. This was also already stated by Qin et al. [8] even with some oxygen added to the inlet gas mixture for biomass gasification tests in a DTR.

In both atmospheres, char yield tends to decrease as temperature increases (Fig. 2). At $1000^{\circ} \mathrm{C}$, char yield is not significantly influenced by the atmosphere, whereas at higher temperature, char yield is much lower under a wet atmosphere. Considering that char formation by pyrolysis gives the same yield in inert and wet atmospheres, the lower char yield in a wet atmosphere at $1200{ }^{\circ} \mathrm{C}$ and $1400^{\circ} \mathrm{C}$ can be explained by its steam gasification. Note that at $1400{ }^{\circ} \mathrm{C}$ in a wet atmosphere, no carbonaceous char could be collected at the output of the drop tube reactor. The mass yield represented in Fig. 2 is then that of the ashes.

The total dry gas yield is higher with the presence of steam in the atmosphere, especially at $1200^{\circ} \mathrm{C}$ and $1400{ }^{\circ} \mathrm{C}$ (Fig. 2). In these conditions, the total dry gas yield is higher than $100 \%$ of initial dry biomass mass, which shows that steam takes part in reactions leading to dry gas formation.

The individual gas mass yields are presented in Figs. 3 and 4 at $1000^{\circ} \mathrm{C}, 1200^{\circ} \mathrm{C}$ and $1400{ }^{\circ} \mathrm{C}$ in a wet atmosphere, and compared to the previous results obtained in an inert atmosphere [14]. Note that the $\mathrm{H}_{2}$ mass yield was multiplied by 10 in Fig. 3 to be represented on the same scale as $\mathrm{CO}$ and $\mathrm{CO}_{2}$.

In the presence of steam in the atmosphere, the $\mathrm{H}_{2}$ and $\mathrm{CO}_{2}$ yields are much higher, whereas the $\mathrm{CO}$ yield is steady or lower than in an inert atmosphere (Fig. 3). At $1200^{\circ} \mathrm{C}$ and $1400^{\circ} \mathrm{C}$, $\mathrm{C}_{2} \mathrm{H}_{2}, \mathrm{C}_{2} \mathrm{H}_{4}$ and $\mathrm{C}_{6} \mathrm{H}_{6}$ yields are significantly lower in a wet atmosphere (Fig. 4). The $\mathrm{CH}_{4}$ yield is surprisingly higher in a wet atmosphere at $1000^{\circ} \mathrm{C}$ and $1200^{\circ} \mathrm{C}$. At $1400^{\circ} \mathrm{C}$, no hydrocarbon at all, including $\mathrm{CH}_{4}$, can be detected in a wet atmosphere.

As shown in Fig. 2 , at $1200{ }^{\circ} \mathrm{C}$ and $1400{ }^{\circ} \mathrm{C}$, the presence of $25 \%$ of steam in the atmosphere induces a significantly higher gas yield. A contribution to this higher gas yield may come from char or soot steam gasification, expressed by reaction (7) assuming that char and soot are composed of carbon only:

$\mathrm{C}+\mathrm{H}_{2} \mathrm{O} \rightarrow \mathrm{CO}+\mathrm{H}_{2}$

However, even by making the gross and probably wrong assumption that the lower soot yield in a wet atmosphere is only due to soot gasification, carbonaceous solids gasification cannot quantitatively explain the difference in dry gas yields between inert and wet atmospheres at $1200^{\circ} \mathrm{C}$ and $1400^{\circ} \mathrm{C}$ (Fig. 3). So, some gas phase reactions implying steam also contribute to this higher gas yield.

Hydrocarbon steam reforming may be one explanation to this observation, and also to the lower $\mathrm{C}_{2} \mathrm{H}_{2}, \mathrm{C}_{2} \mathrm{H}_{4}$ and $\mathrm{C}_{6} \mathrm{H}_{6}$ yields in a wet atmosphere (Fig. 3). Hydrocarbon steam reforming, together with steam gasification of soot, were also mentioned in [8] to explain the increase of gas yield with the addition of steam. Concerning the higher $\mathrm{CH}_{4}$ yield in a wet atmosphere at $1000{ }^{\circ} \mathrm{C}$ and $1200{ }^{\circ} \mathrm{C}$, the same result was also obtained in other works focusing on methane reforming $[25,29]$. This result could be due to an inhibiting effect of $\mathrm{H}_{2} \mathrm{O}$ on methane reforming at temperatures below $1300{ }^{\circ} \mathrm{C}[29]$. 


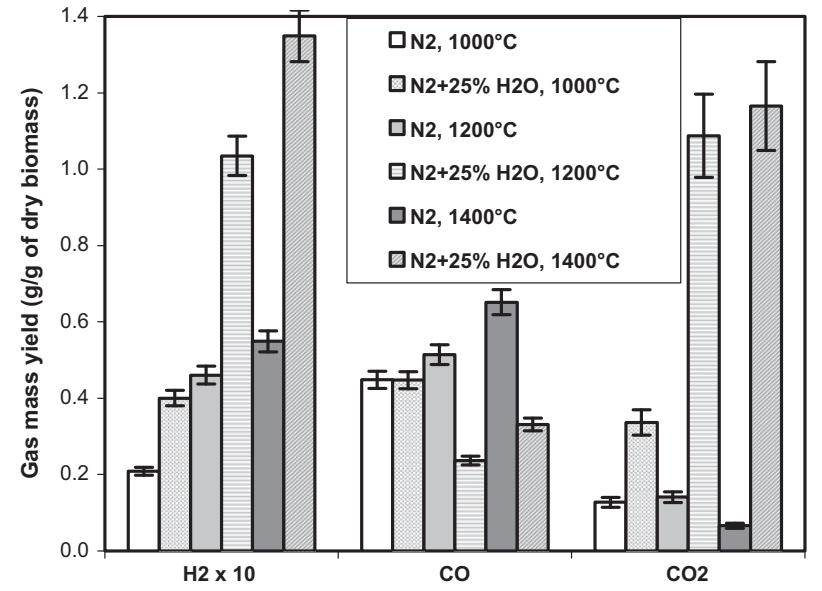

Fig. 3. Experimental mass yields of $\mathrm{H}_{2}, \mathrm{CO}$, and $\mathrm{CO}_{2}$ under inert and wet atmospheres at $1000^{\circ} \mathrm{C}, 1200^{\circ} \mathrm{C}$ and $1400^{\circ} \mathrm{C}$.

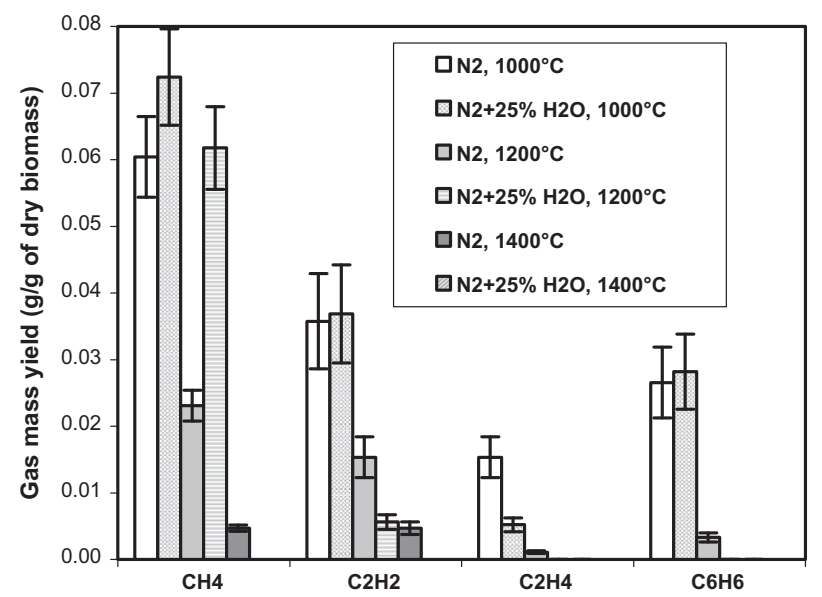

Fig. 4. Experimental mass yields of hydrocarbons under inert and wet atmospheres at $1000^{\circ} \mathrm{C}, 1200^{\circ} \mathrm{C}$ and $1400{ }^{\circ} \mathrm{C}$

Finally, we think that the higher $\mathrm{CO}_{2}$ and $\mathrm{H}_{2}$ yields correlated with a lower $\mathrm{CO}$ yield are largely due to the water-gas shift reaction, with its equilibrium shifted towards $\mathrm{CO}_{2}$ and $\mathrm{H}_{2}$ production in presence of a large excess of steam:

$\mathrm{CO}+\mathrm{H}_{2} \mathrm{O} \leftrightarrow \mathrm{CO}_{2}+\mathrm{H}_{2}$

The higher gas yield in a wet atmosphere above mentioned would then be largely due to this reaction.

This discussion shows that the influence of steam on the products yields cannot be both quantitatively and simply explained. In the GASPAR model, the reactions mentioned above are all taken into consideration, even in a more detailed way for gas phase reactions. The comparison between simulation and experiment results in next section aims at verifying if our representation of phenomena in the model is well adapted to the experiments, and at better understanding the results.

\subsection{Comparison of experiment and simulation results}

Char yields obtained by experiments and by simulations are represented in Fig. 5 for $0.35 \mathrm{~mm}$ particles, at the bottom of the DTR, as a function of temperature and for both inert and wet atmospheres. Simulations are globally in good agreement with experiments. In the model, char formation yield is the same whatever the temperature - about $0.05 \mathrm{~g} / \mathrm{g}$ of dry biomass, calculated from coefficients of Table 4. Lower char yields values are due to char steam gasification, which is described by the kinetic law presented in Table 5. The gasification rate is dependant on the steam partial pressure in the atmosphere. This is why at constant temperature, gasification is enhanced in a wet atmosphere, leading to a lower char yield. In an inert atmosphere, only the steam released by biomass pyrolysis or subsequent gas phase reactions can take part in the char gasification process. Gasification by the steam released during biomass conversion is observed at $1400{ }^{\circ} \mathrm{C}$ in an inert atmosphere (Fig. 5), with a char yield at about $0.03 \mathrm{~g} / \mathrm{g}$ of dry biomass. However, the higher temperature $-1400{ }^{\circ} \mathrm{C}$ - and the addition of steam in the atmosphere are both necessary to almost completely gasify the char, as only ashes then remain.

As said before, gasification by $\mathrm{CO}_{2}$ was not considered in the model. Several experimental studies show that biomass char gasification is at least two times slower in $\mathrm{CO}_{2}$ than in $\mathrm{H}_{2} \mathrm{O}$ [30-32]. In order to check if gasification by $\mathrm{CO}_{2}$ can be assumed to be negligible in comparison to gasification by steam in our conditions, we make the hypothesis that: (1) the ratio of the gasification rate in steam over the gasification rate in $\mathrm{CO}_{2}$ is equal to 2 at constant oxidant partial pressure; (2) in the kinetic law, the exponent relative to oxidant partial pressure is the same for $\mathrm{CO}_{2}$ and $\mathrm{H}_{2} \mathrm{O}$ and equal to 0.7 , which is the value determined for steam gasification of the samples recovered in our DTR (Table 5). This last hypothesis agrees rather well with the results of Van de Steene et al. [32].

We can then calculate the ratio of the gasification rate in steam over the gasification rate in $\mathrm{CO}_{2}$ for different ratios between partial pressures of $\mathrm{H}_{2} \mathrm{O}$ and $\mathrm{CO}_{2}$. The results of these calculations show that:

- For experiments in steam, the gasification rate by steam is at least 15 times that by $\mathrm{CO}_{2}$, so gasification by $\mathrm{CO}_{2}$ can then be neglected in the model.

- For experiments in nitrogen at $1400{ }^{\circ} \mathrm{C}$, the $\mathrm{H}_{2} \mathrm{O}$ partial pressure is about 3 times that of $\mathrm{CO}_{2}$, which leads to a gasification rate by steam equal to 4.4 times that by $\mathrm{CO}_{2}$. In that case, gasification by $\mathrm{CO}_{2}$ is not completely negligible and its consideration in the model would lead to a lower char yield value, closer to the experimental value than the one shown in Fig. 5.

For experiments in nitrogen at 1000 and $1200{ }^{\circ} \mathrm{C}$ for char, and at all temperatures for soot, the steam gasification is very low so that taking into account gasification by $\mathrm{CO}_{2}$ would hardly change the results.

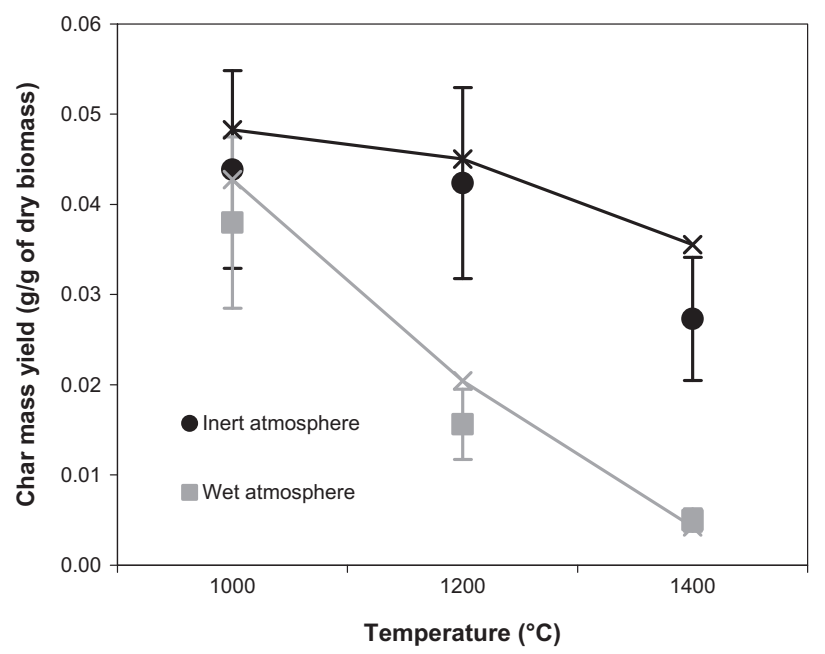

Fig. 5. Experimental (symbols) and calculated (lines) char mass yields for $0.35 \mathrm{~mm}$ particles. 
A comparison between experimental and calculated tar + soot mass yields is now performed in Fig. 6a, at different temperatures and for both inert and wet atmospheres. Note that according to the simulations, the tar species at $1000^{\circ} \mathrm{C}$ and above are only PAHs. Moreover, the "rest" yield is not included in the calculated tar yield. Tar + soot calculated mass yields at $1000^{\circ} \mathrm{C}$ and $1200{ }^{\circ} \mathrm{C}$ in an inert atmosphere agree with experimental results, as gasification kinetic law parameters were adjusted for this purpose, as explained in Section 3.3. In an inert atmosphere at $1400^{\circ} \mathrm{C}$, the simulation is still in good agreement with the experiment. In a wet atmosphere, the simulation results are rather satisfactory at $1400{ }^{\circ} \mathrm{C}$, whereas they are too high compared to experimental results at $1000^{\circ} \mathrm{C}$ and $1200^{\circ} \mathrm{C}$. So, in these conditions, the influence of steam on tar and soot yields is not quantitatively well represented. This may be explained by an underestimation of tar reforming in the model, which would then lead to $\mathrm{CO}$ and $\mathrm{H}_{2}$ formation. The model seems to wrongly favour reaction paths leading to PAHs polymerization and soot formation.

The individual tar and soot mass yields obtained by simulations are shown in Fig. 6b. The calculated tar yields are close to 0 at $1200^{\circ} \mathrm{C}$ and $1400^{\circ} \mathrm{C}$, which is in agreement with the experimental observations mentioned in previous section.

Supplementary simulations were performed at $1400{ }^{\circ} \mathrm{C}$ in order to better understand why soot yield is much lower in a wet atmosphere. The difference can a priori be explained by two phenomena both represented in the model: steam reforming of soot precursors, which limit soot formation, and/or steam gasification of soot particles in a $\mathrm{H}_{2} \mathrm{O}$ rich atmosphere. Fig. 7 shows the calculated soot yield at $1400{ }^{\circ} \mathrm{C}$ :

- in an inert atmosphere,

- in a wet atmosphere without taking soot particles steam gasification into account: the only influence of steam on soot yield then comes from its reaction with soot precursors,

- in a wet atmosphere considering soot particles steam gasification.

Comparing the two first results in Fig. 7 shows that, according to the model, part of soot yield reduction in a wet atmosphere comes from reactions of steam with soot precursors, thus leading to a lower soot formation yield. However, comparing the two last results, it can be seen that soot particles gasification also contributes to the lower soot yield in a wet atmosphere, even if this phenomenon is less important.

The gas yields experimental results are now compared to the simulation results for $0.35 \mathrm{~mm}$ particles at $1200{ }^{\circ} \mathrm{C}$ in Figs. 8 and 9 for an inert and a wet atmosphere respectively. Results are shown here as a function of the reaction zone length. Note that no model result is shown at $1000^{\circ} \mathrm{C}$, as the same conclusions can be drawn at $1000^{\circ} \mathrm{C}$ and $1200{ }^{\circ} \mathrm{C}$. Let us remind that individual

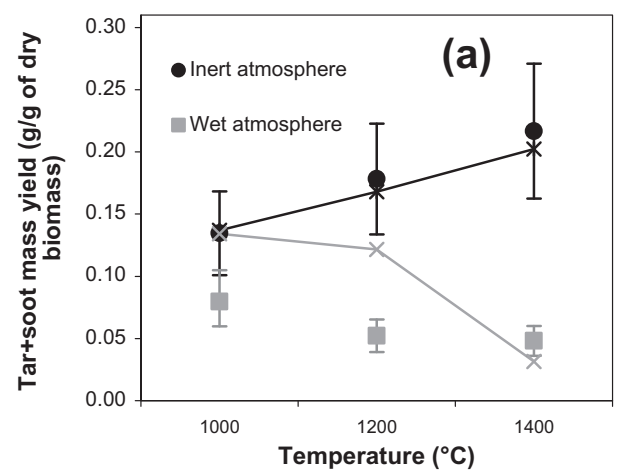

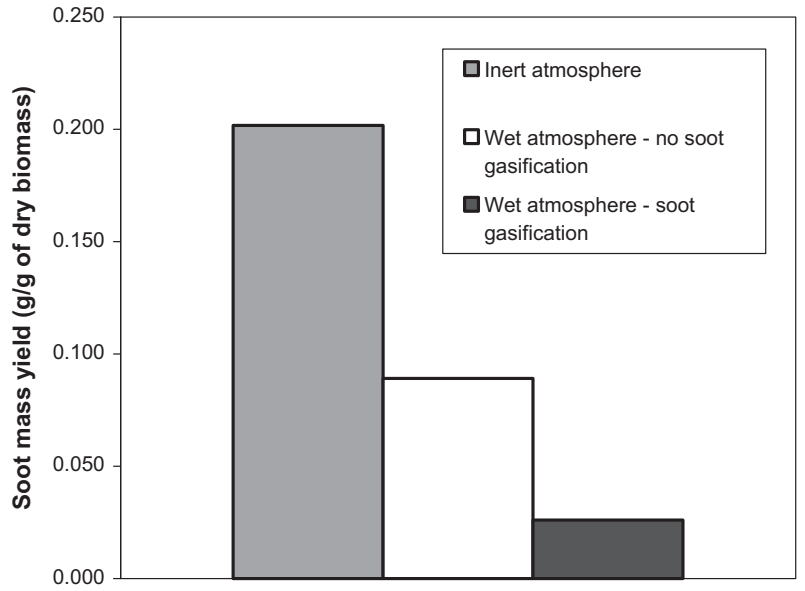

Fig. 7. Calculated soot yields at $1400{ }^{\circ} \mathrm{C}$ in an inert atmosphere and in a wet atmosphere considering or not soot gasification (bottom of the DTR).

gas yields from biomass pyrolysis were adjusted to fit experimental results at $800{ }^{\circ} \mathrm{C}$ (Section 3.2); $\mathrm{C}_{2} \mathrm{H}_{2}$ yield was also adjusted to fit the experimental results at $1200{ }^{\circ} \mathrm{C}$ (Section 3.3). So the simulation results shown here at higher temperature depend on gas reaction and solid gasification modelling.

Fig. 8 shows that the simulation results are globally in good agreement with experimental results in an inert atmosphere. The $\mathrm{H}_{2}$ yield is slightly underestimated, of about $15 \%$, while the $\mathrm{CH}_{4}$ yield is overestimated by the model.

Fig. 9 shows that at $1200{ }^{\circ} \mathrm{C}$ the $\mathrm{CO}, \mathrm{CH}_{4}$ and $\mathrm{C}_{2} \mathrm{H}_{2}$ yields given by the simulation are in rather good agreement with experimental results in a wet atmosphere. The $\mathrm{CO}_{2}$ and $\mathrm{H}_{2}$ yields are underestimated by the model, but their increase along the reaction zone length is qualitatively well represented. When comparing the experimental and calculated tar + soot yields above (Fig. 6a), we made the hypothesis that tar reforming might be underestimated by the model at $1000^{\circ} \mathrm{C}$ and $1200^{\circ} \mathrm{C}$ in a wet atmosphere. This would be in agreement with an underestimation of gas yield in these conditions, in particular $\mathrm{H}_{2}$ yield and $\mathrm{CO}$ or $\mathrm{CO}_{2}$ yield, the latter being dependant on the $\mathrm{CO}$ yield via the water-gas shift reaction.

Another comparison of the experimental and calculated gas mass yields is shown in Fig. 10 for inert and wet atmospheres at $1400{ }^{\circ} \mathrm{C}$. The agreement between model and experiments is then good, which was also shown before for char and tar + soot yields at the same temperature (Figs. 5 and $6 a$ respectively).

\subsection{Influence of particle size on experimental products yields}

The influence of biomass particle size $(0.35 \mathrm{~mm}$ and $0.80 \mathrm{~mm})$ on char, tar + soot and total dry gas yields is shown in Fig. 11 for

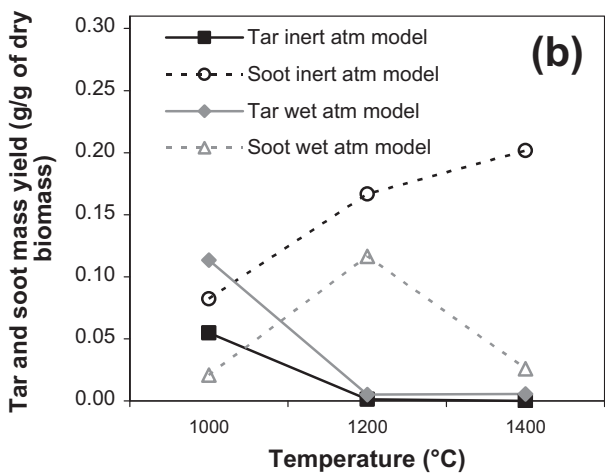

Fig. 6. (a) Experimental (symbols) and calculated (lines) tar + soot mass yields. (b) Calculated tar and soot mass yields - for 0.35 mm particles (bottom of the DTR). 


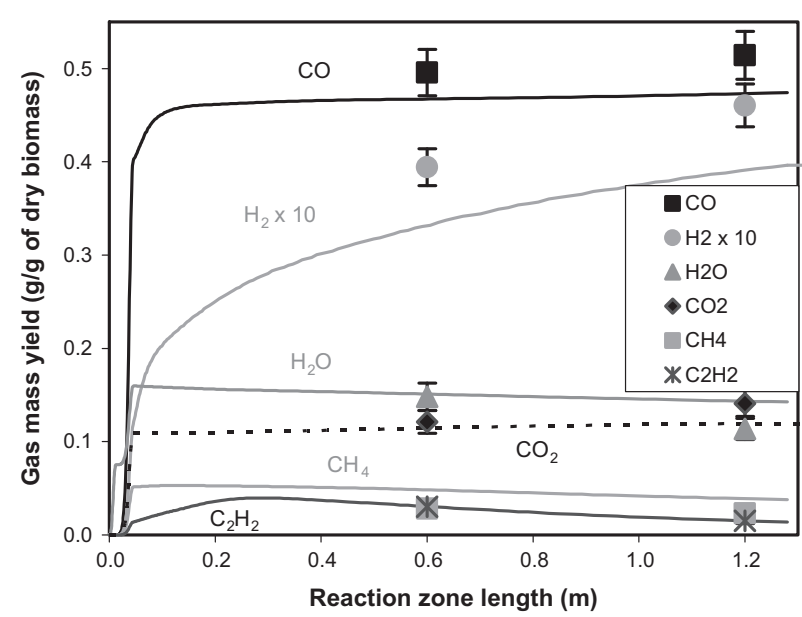

Fig. 8. Experimental (symbols) and calculated (lines) gas mass yields for $0.35 \mathrm{~mm}$ particles at $1200{ }^{\circ} \mathrm{C}$ in an inert atmosphere.

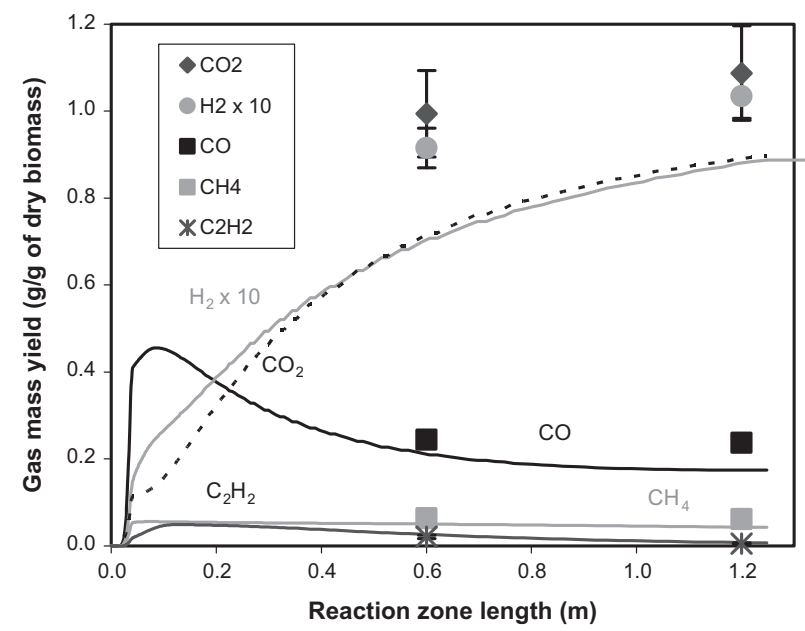

Fig. 9. Experimental (symbols) and calculated (lines) gas mass yields for $0.35 \mathrm{~mm}$ particles at $1200{ }^{\circ} \mathrm{C}$ in a wet atmosphere.

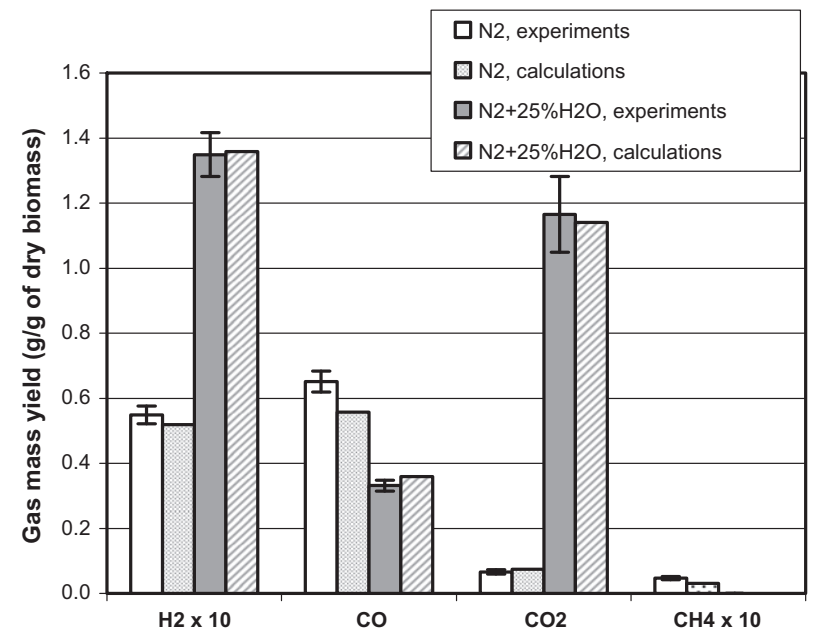

Fig. 10. Experimental and calculated gas mass yields for $0.35 \mathrm{~mm}$ particles at $1400^{\circ} \mathrm{C}$ in inert and wet atmospheres.

experiments under a wet atmosphere. The particle size was found to have no significant effect on gas, tar + soot and char yields at $1000^{\circ} \mathrm{C}, 1200^{\circ} \mathrm{C}$ and $1400{ }^{\circ} \mathrm{C}$, neither in a wet atmosphere, as

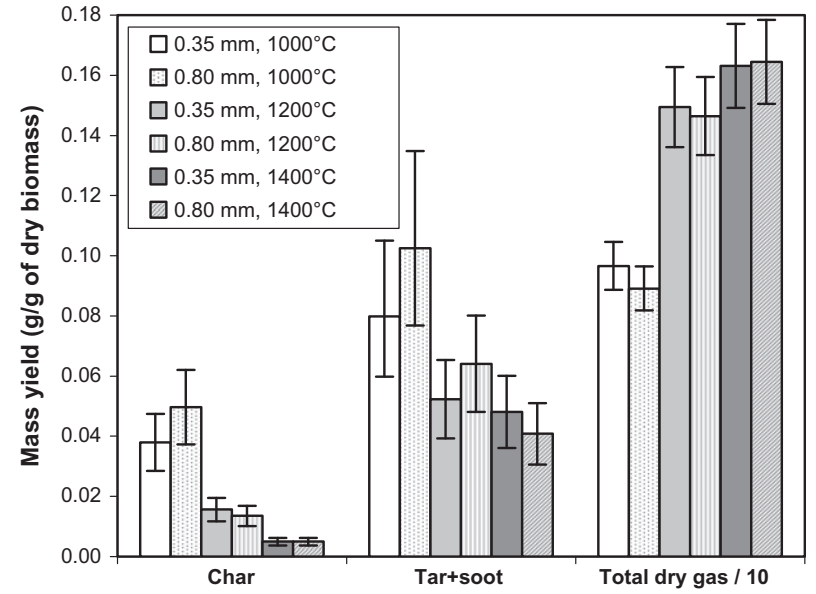

Fig. 11. Experimental char, tar + soot and total dry gas mass yields under a wet atmosphere for $0.35 \mathrm{~mm}$ and $0.80 \mathrm{~mm}$ particles.

illustrated here, nor in an inert one (not shown here). The particle size was also checked to have no influence on the individual gas yields. So the possible heat or mass transfer limitations which may arise in pyrolysis or steam gasification process of a larger particle have no visible consequence on the final yields measured at the output of the DTR. At $1400{ }^{\circ} \mathrm{C}$ in a wet atmosphere, for the $0.80 \mathrm{~mm}$ particles like the $0.35 \mathrm{~mm}$ ones, no carbonaceous char could be collected at the output of the drop tube reactor. The particles are then considered be completely gasified. As already said before, the steam content chosen for the experiments $(25 \mathrm{~mol} \%)$ is in the same order of magnitude as the steam content in an EFR. So these results let us think that particles of about $1 \mathrm{~mm}$ could be well gasified in an entrained flow reactor.

\section{Conclusion}

This study allowed the investigation of wood particle conversion in a drop tube reactor between $1000{ }^{\circ} \mathrm{C}$ and $1400{ }^{\circ} \mathrm{C}$, both through experiments and simulations. It focused in particular on the influence of steam and of wood particle size on the gasification process.

The addition of steam to the atmosphere was experimentally shown to have an influence on tar, soot, char and gas yields, especially at $1200^{\circ} \mathrm{C}$ and $1400^{\circ} \mathrm{C}$. Due to char steam gasification enhancement in a steam-rich atmosphere, char yield is then lower. Concerning soot yield, from 15 to $20 \mathrm{wt} \%$ in an inert atmosphere, it decreases to about $5 \mathrm{wt} \%$ in a wet atmosphere. The total dry gas yield is much higher under a wet atmosphere at $1200{ }^{\circ} \mathrm{C}$ and $1400^{\circ} \mathrm{C}$, and its composition is modified. This can be partly explained by steam gasification of solids - char and soot - which produce gases. However, gas phase reactions, such as hydrocarbons steam reforming and water gas shift, probably also have an important influence on gas yields.

In the experimental conditions which are the closest to the operation conditions of an EFR $-1400^{\circ} \mathrm{C}$, atmosphere with $25 \mathrm{~mol} \% \mathrm{H}_{2} \mathrm{O}$, residence time of $4.4 \mathrm{~s}$ - the char seems to be completely gasified. However, the soot yield still represents about 5 wt\% of the initial dry biomass.

Wood particle size in the range $0.35-0.80 \mathrm{~mm}$ was experimentally shown to have no influence on products yields for a residence time of a few seconds. This lets us think that particles of about $1 \mathrm{~mm}$ could be well gasified in an EFR.

The model appeared to give globally satisfactory results in comparison with experimental ones, concerning char, tar + soot and 
individual gas yields. Only the influence of steam at $1000^{\circ} \mathrm{C}$ and $1200{ }^{\circ} \mathrm{C}$ could still be better represented, maybe by improving the modelling of reactions involved in tar reforming.

The model was used to reach a better comprehension of the involved phenomena. The simulation results showed that the lower soot yield in a wet atmosphere could mainly be explained by reforming of soot precursors, but also by steam gasification of soot particles. In the future, we intend to use the different individual models of GASPAR representing biomass conversion in other numerical models developed for EFR design.

\section{Acknowledgements}

The authors thank Gilles RATEL (CEA) for his help in the last GASPAR calculations. The authors also thank the two reviewers for their valuable comments and suggestions.

\section{References}

[1] Svoboda K, Pohorely M, Hartman M, Martinec J. Pretreatment and feeding of biomass for pressurized entrained flow gasification. Fuel Process Technol 2009;90:629-35.

[2] van der Drift A, Boerrigter H, Coda B, Cieplik MK, Hemmes K. Entrained flow gasification of biomass: ash behaviour, feeding issues and system analyses. ECN-C-04-039. ECN; 2004.

[3] Bitowft B, Andersson LA, Bjerle I. Fast pyrolysis of sawdust in an entrained flow reactor. Fuel 1989;68:561-6.

[4] Zhang Y, Kajitani S, Ashizawa M, Miura K. Peculiarities of rapid pyrolysis of biomass covering medium-and high-temperature ranges. Energy Fuels 2006;20:2705-12

[5] Zhang Y, Kajitani S, Ashizawa M, Oki Y. Tar destruction and coke formation during rapid pyrolysis and gasification of biomass in a drop-tube furnace. Fuel 2010;89:302-9.

[6] Couhert C, Salvador S, Commandré JM. Impact of torrefaction on syngas production from wood. Fuel 2009;88:2286-90.

[7] Hallgren A, Andersson LA, Bjerle I. High temperature gasification of biomass in an atmospheric entrained flow reactor. In: Bridgwater AV, editor. Advances in thermochemical biomass conversion. Cambridge: Blackie Academic and Professional; 1992.

[8] Qin K, Lin W, Jensen PA, Jensen AD. High-temperature entrained flow gasification of biomass. Fuel 2012;93:589-600.

[9] Chen L. Fast pyrolysis of millimetric wood particles between $800{ }^{\circ} \mathrm{C}$ and $1000^{\circ} \mathrm{C}$. PhD thesis. Université Claude Bernard - Lyon 1; 2009.

[10] Vilas E, Skifter U, Jensen AD, López C, Maier J, Glarborg P. Experimental and modeling study of biomass reburning. Energy Fuels 2004;18:1442-50.

[11] Dupont C, Chen L, Cances J, Commandre J-M, Cuoci A, Pierucci S, et al. Biomass pyrolysis: Kinetic modelling and experimental validation under high temperature and flash heating rate conditions. J Anal Appl Pyrolysis 2009;85:260-7.

[12] Pierucci S, Ranzi E. Modelling biomass gasifiers. In: Computer aided chemical engineering. USA: Elsevier; 2009. p. 797-802.
[13] Ranzi E, Cuoci A, Faravelli T, Frassoldati A, Migliavacca G, Pierucci S, et al. Chemical kinetics of biomass pyrolysis. Energy Fuels. 2008

[14] Septien S, Valin S, Dupont C, Peyrot M, Salvador S. Effect of particle size and temperature on woody biomass fast pyrolysis at high temperature (1000$\left.1400{ }^{\circ} \mathrm{C}\right)$. Fuel 2012;97:202-10.

[15] Septien S. High temperature gasification of millimetric wood particles between $800{ }^{\circ} \mathrm{C}$ and $1400^{\circ} \mathrm{C}$. PhD thesis. Institut National Polytechnique de Toulouse; 2011.

[16] Cancès J. Formation et réduction de $\mathrm{NO}_{\mathrm{x}}$ par un charbon, un lignite, un anthracite et un coke de pétrole dans les conditions d'un précalcinateur de cimenterie. PhD thesis. Institut National Polytechnique de Toulouse; 2006.

[17] Commandré JM. Formation des oxydes d'azote lors de la combustion de cokes de pétrole dans des conditions de précalcinateur de cimenterie. $\mathrm{PhD}$ thesis. Institut National Polytechnique de Toulouse; 2002.

[18] Van de Steene L. Thermochimie de la combustion à basses températures de solides pulvérises: application à un charbon. PhD thesis. Institut National Polytechnique de Toulouse; 1999.

[19] Peyrot M, Dupont C, Chen L, Spindler B, Valin S, Cancès J, Fast pyrolysis of millimetric wood particles between $1073 \mathrm{~K}$ and $1273 \mathrm{~K}$ : modelling and experimental validation in the chemical kinetic regime. In: 18th European biomass conference and exhibition, Lyon; 2010.

[20] Simone M, Biagini E, Galletti C, Tognotti L. Evaluation of global biomass devolatilization kinetics in a drop tube reactor with CFD aided experiments. Fuel 2009;88:1818-27.

[21] Brown AL, Dayton DC, Nimlos MR, Daily JW. Design and characterization of an entrained flow reactor for the study of biomass pyrolysis chemistry at high heating rates. Energy Fuels 2001;15:1276-85.

[22] Kee RJ, Rupley FM, Miller JA. The CHEMKIN thermodynamic data base. SAND87-8215B. Sandia National Laboratory; 1990.

[23] Radhakrishnan K. Hindmarsh AC. Description and use of LSODE, the Livermore solver for ordinary differential equations. Technical report UCLR-ID-113855. Lawrence Livermore National Laboratory; 1993.

[24] Skjøth-Rasmussen MS, Glarborg P, Ostberg M, Johannessen JT, Livbjerg H, Jensen $\mathrm{AD}$, et al. Formation of polycyclic aromatic hydrocarbons and soot in fuel-rich oxidation of methane in a laminar flow reactor. Combust Flame 2004; 136:91-128

[25] Valin S, Cancès J, Castelli P, Thiery S, Dufour A, Boissonnet G, et al. Upgrading biomass pyrolysis gas by conversion of methane at high temperature: experiments and modelling. Fuel 2009;88:834-42.

[26] Tree DR, Svensson KI. Soot processes in compression ignition engines. Prog Energy Combust Sci 2007;33:272-309.

[27] Ziegler I. Modélisation cinétique des dépôts de pyrocarbone obtenus par pyrolyse d'hydrocarbures. PhD thesis. Nancy: Institut National Polytechnique de Lorraine; 2004.

[28] Frenklach M, Wang H. Detailed modeling of soot particle nucleation and growth. In: 23rd Symposium (international) on combustion. France: The Combustion Institute. University of Orleans; 1990.

[29] Hiblot $\mathrm{H}$. Etude cinétique du réformage thermique des produits issus de la gazéification de la biomasse. PhD thesis. Institut National Polytechnique de Lorraine; 2010.

[30] Klose W, Wölki M. On the intrinsic reaction rate of biomass char gasification with carbon dioxide and steam. Fuel 2005;84:885-92.

[31] Stoltze S, Gasification of straw in a large-sample TGA. Part II. In: Nordic seminar on solid fuel reactivity, Gothenburg; 1993.

[32] Van de steene L, Tagutchou JP, Escudero Sanz FJ, Salvador S. Gasification of woodchip particles: Experimental and numerical study of char- $\mathrm{H}_{2} \mathrm{O}$, char- $-\mathrm{CO}_{2}$, and char- $\mathrm{O}_{2}$ reactions. Chem Eng Sci 2011;66:4499-509. 